Dept. of Food Hygiene, Port-Said Lab.,

Animal Health Research Institute, Dokki, Giza, Egypt.

\title{
LEVELS OF LEAD AND CADMIUM RESIDUES IN TISSUES OF BOVINE SLAUGHTERED IN PORT-SAID GOVERNORATE
}

\author{
(With 5 Tables)
}

\section{By \\ H.EL-S.M. FARAG; ZIENAB M. NEIAZY* and M.A.M. YASSIEN**}

* Dept. of Food Hygiene, Lab. Diagnosis and Food Hygiene, Animal Health Research Institute, Dokki-Giza.

** Dept. of Food Hygiene, Faculty of Veterinary Medicine, Suez Canal University.

(Received at 16/8/2009)

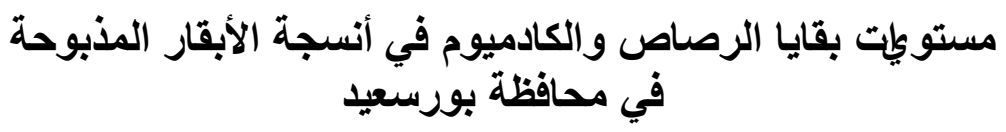

حسن السبل محد فرج ، زينب محمود نيازي ، مكرم احد بيس

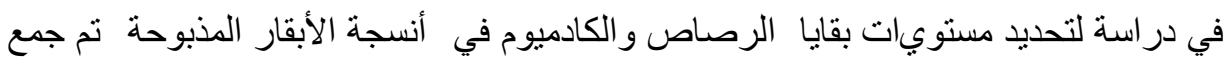

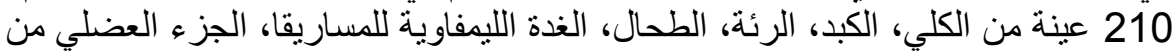

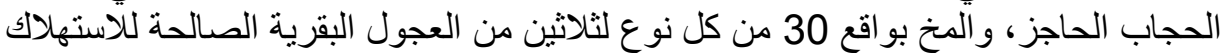

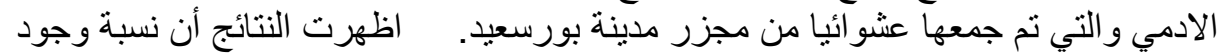

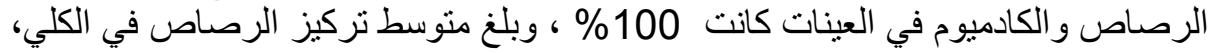

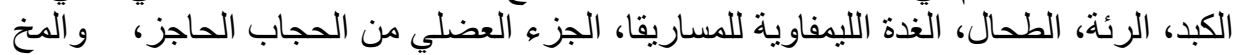

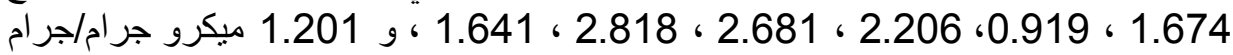

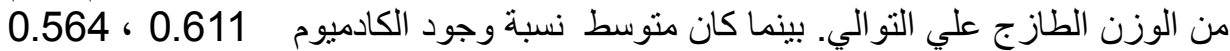

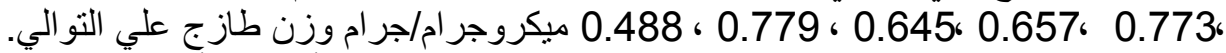

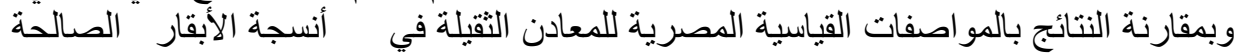
للاستهلاك الآدمي كانت هنالك زيادة كبيرة في كل العينات عن الحد المسموح بـاته لمستوي

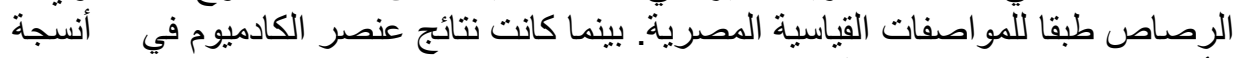
الأبقار الصالحة للاستهلاك الآدمي تقترب نسبيا من الحد المسموح به به ووجد 46 (21,904) عينة من إجمالي العينات تزيد عن الحد المسموح به لمستوي الكادميوم طبقا

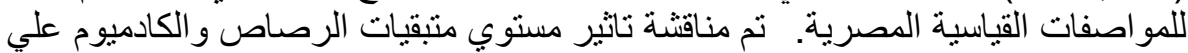
الصحة العامة. 


\section{SUMMARY}

Two hundred and ten samples from bovine kidneys, livers, lungs, spleens, mesenteric lymph nodes, muscular portions of diaphragm and brains were collected randomly from 30 fit bovine carcasses for human consumption from Port-Said abattoirs. Lead and cadmium residues were analyzed. Lead and cadmium were detected in $100 \%$ of the specimens. Mean lead values in the examined samples obtained from kidney, liver, lung, spleen, mesenteric lymph node, muscular portion of diaphragm and brain for bovine were 1.674, 0.919, 2.206, 2.681, 2.818, 1.641 and $1.201 \mu \mathrm{g} / \mathrm{g}$ wet weight respectively. While mean cadmium values in the examined samples were $0.611,0.564 ; 0.773 ; 0.657 ; 0.645 ; 0.779$ and $0.488 \mu \mathrm{g} / \mathrm{g}$ on the basis of wet weight respectively. All examined samples $210(100 \%)$ exceeded the recommended level of lead established by E.O.S.Q.C while $46(21.904 \%)$ among the total samples could be considered unsuitable for human consumption entirely as it approximate the critical levels of cadmium established by E.O.S.Q.C. The effects of lead and cadmium on the public health were discussed.

Key words: Lead, cadmium, offal, bovine carcases.

\section{INTRODUCTION}

From the public health stand point of view attention must be paid, not only to the study of the nutritional benefits of meat and their products, but also to the safety aspects, especially those concerns with the presence of harmful pollutants substances to human health.

Heavy metals make up one of the most important groups of pollutants. From the point of food analyst, heavy metals which are referred to the inorganic elements, metallic in nature had a hazardous effect even at relatively low concentration. Moreover, not broken down at all or may chelated over a long time scale to become permanent additions to the environment and animal consequently human tissues. These heavy metals are not needed as structural components of organs and tissues, not constituents of body fluids and not a constituent or activators of enzymes system in body except traces of arsenic, which are needed in a very low concentration (Royal Commission on Environmental Pollution, 1979).

Contamination of animal tissues by heavy metals is arisen mainly from the contamination of animal requirements from feed, water, air beside the accidental addition which can be associated with soils 
naturally high in these elements, environmental pollution from local industry, feeding grain treated with the toxic metals, and the use of impure chemicals (Hecht, 1990). Thus heavy metals enter food chain and lead to unwanted residues in food animals. These residues have a pharmacological action and conversion products, then are transmitted to the target organs in the animal body which are mainly the edible offal of the slaughtered food animals (Gracey and Collins, 1992).

These heavy metals are undesirable and produce no lesion in animal tissues that can be observed post-mortem except in heavy intoxication (Royal Commission on Environmental Pollution, 1979).

The absorbed lead in animal had a tendency to accumulate and produced pathological changes in bone, liver, kidney (National Academy of Science, 1972) and in central nervous system (Wells et al., 1975). These changes include fatty infiltration, necrotic foci and billiary cirrhosis in liver (Gouda, et al., 1985; Gracy and Collins, 1992), chronic diffuse glomerulonephritis with edema (Gracy and Collins, 1992; Thiel, 1994) and fibrosis (Schraishuhn et al., 1992) of kidney. Also gastroenteritis, epicardial and endocardial hemorrhages and pulmonary congestion (Gracy and Collins, 1992) has been occurred. On the other hand cadmium intoxication in animal has characterized by an increase in the weight of spleen and thymus, thyroid and adrenal gland with an increasing in the incidence of the pyelonephritis, anemia and bone demineralization (Glaser and Muller-Peddingghaus, 1978; Rotkiewiez et al., 1979). Hyperemia, edema, degenerative changes in the heart, muscle and lung and thickening of the keratinized layer of rumen reticulum and omasium were recorded as a signs of cadmium intoxication (Rotkiewiez et al., 1979).

Although certain amounts of lead and cadmium can be tolerated by the human being, they are absolutely toxic at certain level. Excessive intake of heavy metals in his food had led to many cases of intoxication, ranged between the gastrointestinal disturbance to liver and kidney dysfunction and lung carcinoma (Gracey and Collins, 1992). Also lead causes encephalopathy in children usually followed by permanent CNS damage with signs of impaired neurobehavioral, cognitive and electrophysiological deficits (Carl, 1991; WHO, 1995). While in adult avitaminosis, loss of weight and anemia (WHO, 1980; Carl, 1991), hepatocellular injury and dysfunction of the liver (Denuman et al., 1983; Carl, 1991), kidney damage, gastrointestinal irritation (Carl, 1991), tumor formation (Carrington et al., 1993) and cardiovascular problems with hypertension (Staessen et al. (1996) has been recorded. Cadmium 
intoxication in human result in renal damage and dystrophic changes associated with hypercalcuria, glucosuria, proteinuria and aminoaciduria with hypertension (Ragan and Mast, 1990; Carl, 1991; Gracey and Colins, 1992) and itia-itia disease (FAO/WHO, 1972). Also a dystrophic change in the liver and testis (Gruenwedel, 1990; Gracey and Colins, 1992) associate with anemia (Robards and Worsfold, 1991) has been reported.

The aim of the present study is to determine the lead and cadmium levels in certain bovine edible offal (kidney, liver, lung, spleen, mesenteric lymph node, diaphragm and brain) in order to ensure the safety of the consumer and direct the attention to their public health significance

\section{MATERIALS and METHODS}

\section{1- Collection of the samples:}

A total of 210 random samples of various bovine edible offal (30 each of kidney, liver, lung, spleen, mesenteric lymph node, part of the muscular portion of the diaphragm, and brain) were selected from 30 of apparently healthy and fit for human consumption bovine carcasses from Port- Said abattoir. Each individual sample was placed separately into plastic bag thoroughly identified and delivered to the laboratory, where they were stored at $\left(-20^{\circ} \mathrm{c}\right)$ until lead and cadmium residues analyzed.

\section{2- Laboratory technique:}

\section{2- 1-Preparation of tissues}

The tissues were prepared and freed from extraneous fat, tendon and major blood vessels according to van derVeen and Vreman (1986).

\section{2- 2-Extraction of residual lead and cadmium:}

One gram of the sample was placed in a clean and dry $20 \mathrm{ml}$ Teflon tube with screw capped and treated with $5 \mathrm{ml}$ of nitric-perchloric acid mixture $(4: 1 \mathrm{v} / \mathrm{v})$. The samples were left to be stand for the cold digestion overnight, then the samples were heated in water bath at $70{ }^{\circ} \mathrm{C}$ for $3 \mathrm{hr}$. The heat turned off and the screw capped was unbound, just to crimp on the mouth of the tube to expel nitrous gases, tubes allowed to cool.

The digest was diluted with deionized water where its volume adjusted to $25 \mathrm{ml}$ in a volumetric flask. The obtained mixture $(25 \mathrm{ml})$ was filtrated through a glass funnel containing Whatman filter paper No.1.

For each sample the obtained clear filtrate was divided between two clean dry stopper bottles and preserved at refrigerator until the time 
of assessment of the metal concentration according to Morcombe et al. (1994) and Atta (1995).

\section{2-3- Assessment of residue by atomic absorption spectrophotometer:}

The two clear filtrate of the same sample was investigated for the presence of lead and cadmium by using the atomic absorption spectrophotometer (210VGP, Buck Scientific, Inc., Fort Point St., East Norwalk, CT., U.S.A.). The estimated levels of lead and cadmium for each sample were calculated as the mean of the metal levels in the two bottles expressed as $\mu \mathrm{g} / \mathrm{g}$ on the basis of fresh weight sample.

\section{3- Statistical Methods}

Minimum, maximum, mean, standard deviation and standard error of mean as well as frequency distribution were used to describe data. These tests were analyzed using the Statistical Package for Social Scientists (SPSS) for windows 16.0 (SPSS Inc., Chicago, IL, and USA).

\section{RESULTS}

Table 1: Statistical analytical results of the estimated lead levels $(\mu \mathrm{g} / \mathrm{g}$ wet weight) in the examined edible offal and muscle.

\begin{tabular}{|l|c|c|c|c|c|c|c|}
\hline & \multicolumn{7}{|c|}{ Type of samples } \\
\cline { 2 - 8 } & kidney & Liver & Lung & Spleen & $\begin{array}{c}\text { Lymph node } \\
\text { (mesenteric) }\end{array}$ & $\begin{array}{c}\text { Diaphragm } \\
\text { (muscular part) }\end{array}$ & Brain \\
\hline $\begin{array}{l}\text { Valid No. } \\
\text { of samples }\end{array}$ & 30 & 30 & 30 & 30 & 30 & 30 & 30 \\
\hline Minimum & 0.037 & 0.006 & 0.025 & 0.014 & 0.020 & 0.069 & 0.180 \\
\hline Maximum & 5.804 & 4.642 & 5.768 & 5.970 & 5.769 & 5.004 & 4.457 \\
\hline Mean & 1.674 & 0.919 & 2.206 & 2.681 & 2.818 & 1.641 & 1.201 \\
\hline SD & 2.058 & 1.152 & 1.986 & 2.040 & 2.298 & 1.540 & 1.660 \\
\hline SE & 0.376 & 0.210 & 0.363 & 0.372 & 0.420 & 0.281 & 0.303 \\
\hline
\end{tabular}

$\mathrm{SD}=$ Standard Deviation $\mathrm{SE}=$ Standard Error of Mean

Table 2: Statistical analytical results of the estimated cadmium levels $(\mu \mathrm{g} / \mathrm{g}$ wet weight) in the examined edible offal and muscle.

\begin{tabular}{|l|c|c|c|c|c|c|c|}
\hline & \multicolumn{7}{|c|}{ Type of samples } \\
\cline { 2 - 8 } & kidney & Liver & Lung & Spleen & $\begin{array}{c}\text { Lymph node } \\
\text { (mesenteric) }\end{array}$ & $\begin{array}{c}\text { Diaphragm } \\
\text { (muscular part) }\end{array}$ & Brain \\
\hline $\begin{array}{l}\text { Valid No. of } \\
\text { samples }\end{array}$ & 30 & 30 & 30 & 30 & 30 & 30 & 30 \\
\hline Minimum & 0.041 & 0.098 & 0.104 & 0.018 & 0.143 & 0.177 & 0.081 \\
\hline Maximum & 1.133 & 1.138 & 1.135 & 1.324 & 1.141 & 1.155 & 0.851 \\
\hline Mean & 0.611 & 0.564 & 0.773 & 0.657 & 0.645 & 0.779 & 0.488 \\
\hline SD & 0.366 & 0.358 & 0.247 & 0.396 & 0.306 & 0.262 & 0.332 \\
\hline SE & 0.067 & 0.654 & 0.045 & 0.072 & 0.056 & 0.048 & 0.061 \\
\hline
\end{tabular}

$\mathrm{SD}=$ Standard Deviation $\quad \mathrm{SE}=$ Standard Error of Mean 
Table 3: Distribution of the investigated offal and muscle into classes with regard to the frequency of the lead concentrations ( $\mu \mathrm{g} / \mathrm{g}$ wet weight).

\begin{tabular}{|c|c|c|c|c|c|c|c|c|c|c|c|c|}
\hline \multirow{3}{*}{ Samples } & \multicolumn{12}{|c|}{ Concentration class ( $\mu \mathrm{g} / \mathrm{g}$ on wet weight basis) } \\
\hline & \multirow{2}{*}{$<0.003$} & \multirow{2}{*}{$0.004-.01$} & \multirow{2}{*}{$0.02-0.1$} & \multirow{2}{*}{$0.2-1.0$} & \multirow{2}{*}{$1.1-1.5$} & \multirow{2}{*}{$1.6-2.0$} & \multirow{2}{*}{$2.1-3.0$} & \multirow{2}{*}{$3.1-4.0$} & \multirow{2}{*}{$4.1-5.0$} & \multirow{2}{*}{$5.1-6.0$} & \multicolumn{2}{|c|}{ Total } \\
\hline & & & & & & & & & & & No. & $\%$ \\
\hline Kidney & ---- & ---- & 1 & 12 & 6 & 2 & ---- & 1 & 5 & 3 & 30 & 100 \\
\hline Liver & ---- & 2 & 1 & 11 & 10 & 2 & 2 & ----- & 2 & ---- & 30 & 100 \\
\hline Lung & ---- & ---- & 2 & 4 & 9 & 2 & 2 & 2 & 5 & 4 & 30 & 100 \\
\hline Spleen & ---- & ---- & 2 & 3 & 7 & 2 & 2 & 1 & 7 & 6 & 30 & 100 \\
\hline $\begin{array}{l}\text { Lymph node } \\
\text { (mesenteric) }\end{array}$ & ---- & ---- & 4 & 7 & 1 & 1 & 1 & 2 & 6 & 8 & 30 & 100 \\
\hline $\begin{array}{l}\text { Diaphragm } \\
\text { (muscular part) }\end{array}$ & ---- & ---- & 2 & 5 & 9 & 6 & 2 & 4 & ---- & 2 & 30 & 100 \\
\hline Brain & ---- & ---- & ---- & 18 & 6 & ---- & ---- & ---- & 6 & ---- & 30 & 100 \\
\hline
\end{tabular}

Table 4: Distribution of the investigated offal and muscle into classes with regard to the frequency of the cadmium concentrations ( $\mu \mathrm{g} / \mathrm{g}$ wet weight).

\begin{tabular}{|c|c|c|c|c|c|c|c|c|c|c|c|c|}
\hline \multirow{3}{*}{ Samples } & \multicolumn{12}{|c|}{ Concentration class ( $\mu \mathrm{g} / \mathrm{g}$ on wet weight basis) } \\
\hline & \multirow{2}{*}{$<0.003$} & \multirow{2}{*}{$0.004-.01$} & \multirow{2}{*}{$0.02-0.1$} & \multirow{2}{*}{$0.2-1.0$} & \multirow{2}{*}{$1.1-1.5$} & \multirow{2}{*}{$1.6-2.0$} & \multirow{2}{*}{$2.1-3.0$} & \multirow{2}{*}{$3.1-4.0$} & \multirow{2}{*}{$4.1-5.0$} & \multirow{2}{*}{$5.1-6.0$} & \multicolumn{2}{|c|}{ Total } \\
\hline & & & & & & & & & & & No. & $\%$ \\
\hline Kidney & ---- & ---- & 4 & 9 & 13 & 4 & ---- & ---- & ---- & ---- & 30 & 100 \\
\hline Liver & ---- & 1 & 3 & 9 & 13 & 4 & ---- & ---- & ---- & ---- & 30 & 100 \\
\hline Lung & ---- & ---- & ---- & 4 & 21 & 5 & ---- & ---- & ---- & ---- & 30 & 100 \\
\hline Spleen & ---- & ---- & ---- & 10 & 14 & 6 & ---- & ---- & ---- & ---- & 30 & 100 \\
\hline $\begin{array}{l}\text { Lymph node } \\
\text { (mesenteric) }\end{array}$ & --- & ---- & ---- & 9 & 18 & 3 & ---- & ---- & ---- & ---- & 30 & 100 \\
\hline $\begin{array}{l}\text { Diaphragm } \\
\text { (muscular part) }\end{array}$ & ---- & ---- & ---- & 5 & 19 & 6 & ---- & ---- & ---- & ---- & 30 & 100 \\
\hline Brain & ---- & ---- & ---- & 6 & 6 & 18 & ---- & ---- & ---- & ---- & 30 & 100 \\
\hline
\end{tabular}


Assiut Vet. Med. J. Vol. 55 No. 123 October 2009 
Table 5: Agreement and non agreement number and percentage of the examined samples with E.O.S.Q.C. limits.

\begin{tabular}{|c|c|c|c|c|c|c|c|c|c|c|c|c|c|c|c|c|}
\hline \multirow{4}{*}{ Samples } & \multicolumn{8}{|c|}{ Lead } & \multicolumn{8}{|c|}{ Cadmium } \\
\hline & \multirow{3}{*}{ Mean } & \multirow{3}{*}{$\begin{array}{c}\text { E.O.S.Q.C. } \\
\text { level } \\
\text { ( } \mu \mathrm{g} / \mathrm{g} \text { wet } \\
\text { tissue) }\end{array}$} & \multicolumn{6}{|c|}{ Number of sample } & \multirow{3}{*}{ Mean } & \multirow{3}{*}{$\begin{array}{c}\text { E.O.S.Q.C. } \\
\text { level } \\
\text { ( } \mu \mathrm{g} / \mathrm{g} \text { wet } \\
\text { tissue) }\end{array}$} & \multicolumn{6}{|c|}{ Number of sample } \\
\hline & & & \multicolumn{2}{|c|}{$\begin{array}{l}\text { No. of } \\
\text { agree }\end{array}$} & \multicolumn{2}{|c|}{$\begin{array}{c}\text { No. of not } \\
\text { agree }\end{array}$} & \multicolumn{2}{|c|}{ Total no. } & & & \multicolumn{2}{|c|}{ No. of agree } & \multicolumn{2}{|c|}{$\begin{array}{c}\text { No. of } \\
\text { not agree }\end{array}$} & \multicolumn{2}{|c|}{ Total no. } \\
\hline & & & No. & $\%$ & No. & $\%$ & No. & $\%$ & & & No. & $\%$ & No. & $\%$ & No. & $\%$ \\
\hline Kidney & 1.674 & Nil & 00 & 00 & 30 & 100 & 30 & 100 & 0.611 & $\leq 2.00$ & 26 & 86.67 & 4 & 13.33 & 30 & 100 \\
\hline Liver & 0.919 & Nil & 00 & 00 & 30 & 100 & 30 & 100 & 0.564 & $\leq 2.00$ & 26 & 86.67 & 4 & 13.33 & 30 & 100 \\
\hline Lung & 2.206 & Nil & 00 & 00 & 30 & 100 & 30 & 100 & 0.773 & $\leq 2.00$ & 25 & 83.33 & 5 & 16.67 & 30 & 100 \\
\hline Spleen & 2.681 & Nil & 00 & 00 & 30 & 100 & 30 & 100 & 0.657 & $\leq 2.00$ & 24 & 80.00 & 6 & 20.00 & 30 & 100 \\
\hline $\begin{array}{l}\text { Lymph node } \\
\text { (mesenteric) }\end{array}$ & 2.818 & Nil & 00 & 00 & 30 & 100 & 30 & 100 & 0.645 & $\leq 2.00$ & 27 & 90.00 & 3 & 10.00 & 30 & 100 \\
\hline $\begin{array}{l}\text { Diaphragm } \\
\text { (muscular part) }\end{array}$ & 1.641 & Nil & 00 & 00 & 30 & 100 & 30 & 100 & 0.779 & $\leq 2.00$ & 24 & 80.00 & 6 & 20.00 & 30 & 100 \\
\hline Brain & 1.201 & Nil & 00 & 00 & 30 & 100 & 30 & 100 & 0.488 & $\leq 2.00$ & 12 & 40.00 & 18 & 60.00 & 30 & 100 \\
\hline Total & & & 00 & 00 & 210 & 100 & 210 & 100 & & & 164 & 78.10 & 46 & 21.90 & 210 & 100 \\
\hline
\end{tabular}




\section{DISCUSSION}

Pollution of the environment with heavy metals is a serious problem due to the industrial growing and the improper hygienic practices leading to a build-up in the soil and environment where grazing animals may ingest them and hazardous effect occur even at a relatively low concentration (Royal Commission on Environmental Pollution, 1979).

The results represented in Table 1 revealed that the mean lead values in the bovine kidney, liver, lung, spleen, mesenteric lymph node, muscular portion of diaphragm and brain samples were 1.674, 0.919, $2.206,2.681,2.818,1.641$ and $1.201 \mu \mathrm{g} / \mathrm{g}$ wet weight respectively. The obtained results were lower than the results recorded by Mousa and Samaha (1993); Korénekova et al. (1998) while higher than those reported by Doganoc (1997); Kottferova and Korénekova (1997). The higher results may be attributed to that the animals may be held in industrialized areas or grazing upon near highways (Van Hassel et al., 1980; Kreuzer and Rosopulo, 1981), high ability of lead to spread widely through environment (WHO, 1977; Monkiewicz et al., 1986) and the increased level of lead in animal feed such as grass, hay, forage, silage and sludge (Van der Veen and Vreman, 1986; Salisbury et al., 1991). Consequently lead has absorbed and accumulates in bones, liver and kidneys (Vos, et al., 1987).

The given results in Table 2 revealed that the mean cadmium values in the bovine kidney, liver, lung, spleen, lymph node, diaphragm and brain samples were $0.611,0.564,0.773,0.657,0.645,0.779$ and $0.488 \mu \mathrm{g} / \mathrm{g}$ wet weight respectively. Our results were lower than the results recorded by Doganoc (1996); Korénekova et al. (1998), but higher than those reported by Jorhem et al. (1996); Kottferova and Korénekova (1997). The higher results may be attributed to the widespread industrial uses of cadmium and their highly ability to spread through environment (Venäläinen et al., 1996; Doganoc 1999). Consequently cadmium inter the food chain via the use of the sewage sludge and the phosphate compounds as land's fertilizers results in an increased the cadmium level in the animal's feed, and animals tissues (Robards and Worsfold, 1991; Morcombe et al., 1994).

Also from Table $1 \& 2$ high levels of lead and cadmium in the lung, lymph node and spleen may be attributed to that the main routes of contamination is through inhalation followed by ingestion. This is agree with the result recorded by Fkhry and Abd El-Fadil (1992) who pointed 
that about $40-80 \%$ of the lead as a pollutant find its way to the body via the lungs, while about $10 \%$ was obtained from the contaminated food and water through the intestine. On the other hand the high levels of cadmium may be attributed to that the main sources of cadmium contamination were mining, fossil fuel, the coal combustion and consequently long range aerial transport and air born contamination (Sharma et al., 1982; Ronneau and Cara, 1984).

The obtained results in Table 3, 4 and 5 showed that lead and cadmium were detected in $100 \%$ (210) of the examined samples. Although $25.71 \%$ (45) of the examined samples were ranged from 4.1 to $6 \mu \mathrm{g} / \mathrm{g}$ wet weight for lead, most of the examined samples were ranged from 0.2 to $1.5 \mu \mathrm{g} / \mathrm{g}$ wet weight for lead and cadmium with a percentage of $51.43 \%$ (108) and $74.29 \%$ (156) respectively. Regarding lead residues $210(100 \%)$ of the samples was extremely exceeded the Egyptian permissible limits thus none of the samples were in agreement with the level established by E.O.S.Q.C., (1993). While 46 (21.904\%) of the examined samples for cadmium could be considered unsuitable for human consumption according to E.O.S.Q.C., (1993). The majority of the samples levels of $\mathrm{Cd}$ were relatively approaching the maximum of the Egyptian permissible limits for $\mathrm{Cd}$ ( $\leq 2 \mu \mathrm{g} / \mathrm{g}$ wet tissues). The higher ranges of lead and cadmium may be attributed to that the animals may be held in industrialized areas or grazing upon near highways (Kreuzer and Rosopulo, 1981). But the varied and wide range of each lead and cadmium concentration could be caused mainly by the difference between animal's exposure to the source of pollution, age, feed composition and individual differences (Kreuzer et al., 1978; Vos et al., 1987).

The discharge of heavy metals from industry are unlikely to be removed by leaching, due to the fact that heavy metals not broken down at all or may chelated over a long time scale to become permanent additions to the environment and animal consequently human tissues (Royal Commission on Environmental Pollution, 1979). Consequently heavy metals enter the human body via food, water, and air and by accumulation in the organisms endanger our health (Hecht, 1990).

Thus to ensure the safety of the consumer, it is recommended that farms should be far away from the highway, off dump sites or the industrial zone, introduction of quality assurance measures for all the components of the agriculture and animals industry, a sensitive and economic analytical technical program should be developed during the adoption of the ante-mortem and post-mortem inspection to monitoring 
of metals in animal tissues, feed, air and water, allow a correct approach to the toxicological problems associated with the individual metal in the carcasses. Only edible offal of the animal less than two years is that one which could be consumed safely while offal and muscle tissues especially those of old animals bred in polluted zones, should be judged as unfit for human food and Strictly quality control procedures must be applied in meat production.

\section{REFERENCES}

Atta, M. (1995): Cadmium and lead contamination of Kafer El-Sheikh drainage waters and fish. Assiut Journal of Agricultural Sciences. 26 (2) 171-181.

Carl, M. (1991): Heavy metals and others trace elements. Monograph on residues and contaminants in milk and milk products. chap. 6, pp. 113, International dairy federation, Belgium. of lead. Food Addit. Contam. 10: 325-335.

Carrington, C.; Sheehan, D. and Bolger, P. (1993): Hazard assessment of lead. Food Addit. Contam. 10: 325-335.

Denuman, B.; Hamdi, E.; Fox, C. and Frazola, A. (1983): Carbon tetrachloride toxicity. Hepatostructural and enzymatic changes. Arch. Environ. Hl th. 7: 630-640.

Doganoc, D. (1996): Lead and cadmium concentrations in meat, liver and kidney of Slovenian cattle and pigs from 1989 to 1993. Food Addit Contam.13 (2) 237-241.

Doganoc, D. (1997): Degree of contamination of food of animal origin with chlorinated hydrocarbons, PCBs, metals and nonmetals in period from 1984 to 1994 . Zb. Vet. Fak. Univ. Ljubljana. 34 (1) $5-12$.

Doganoc, D. (1999): Cadmium in food of animal origin from Slovenia: Concentrations in tissues of pigs and cattle during the period from 1993-1998. Zb. Vet. Fak. Univ. Ljubljana. 36 (2) 231-242.

E.O.S.Q.C. (1993): Egyptian Organization for Standardization and Quality Control. Maximum levels for heavy metal contaminants in food. ES: 2360.

FAO/WHO (1972): Joint Expert Committee on food Additives, Evaluation of certain food additives and contaminants. WHO Technical Report Series No. 505, Geneva. 
Fkhry, Fatma M. and Abd El-Fadil, H. (1992): Evaluation of lead toxicity in broilers with special reference to its cumulative effect on the levels of some elements in various tissues. Zag. Vet. J. 20 (3) 311-322.

Glaser, U. and Muller-Peddingghaus, R. (1978): Chronic oral cadmium dosing of sheep, Toxicological and pathomorphological studied. Zentralblatt für Veterinarmedizin. 25 A (10) 821-836.

Gouda, I.; Aziz, S.; Ahmed, A.; Lotfi, M.; Soliman, M. and Abd El-Azizi, $S$. (1985): Changes in some liver function in experimentally lead-poisoning goats. Archiv Für Eperimentelle Veterinarmedizin. 39 (2):257-257.

Gracey, J. and Collins, D. (1992): Meat Hygiene. $9^{\text {th }}$ Ed., ELBS with Baillier Tindell. Chap. 10, pp. 205-221. London. U.K.

Gruenwedel, D. (1990): Industrial and environmental chemicals in the humans food chain: inorganic chemicals. In "Chemicals in the human food chain”; (Winter, C. w., Sieber, J. n., Nuckton, c. F. eds) pp. 129-182. Van Nostrand Reinhold, New York.

Hecht, H. (1990): Umweltbedingte Rückstünde in tierischen Geweben. Fleischwirtschaft. 70 (90) 1016-1028.

Jorhem, L.; Sundstrüm, B.; Engman, J.; Åstrand, Y.; Ates, C. and Olsson, I. (1996): Levels of certain trace elements in beef and pork imported to Sweden. Food Addit. Contam. 13 (7) 737-745.

Korénekova, B.; Nad, P. and Skalická, M. (1998): The effect of industrial emissions on heavy metal occurrence in organ and tissues of cattle in the vicinity of Košice. J. Trace and Microprobe Techniques. 16 (4) 445-452.

Kottferova, J. and Korénekova, B. (1997): Comparison of the occurrence of risk elements in bulls and dairy cows coming from the fallout region of a metallurgical plant on the territory of Slovakia. Arch. Tierz. Dummerstorf. 40 (4) 309-316.

Kreuzer, W. and Rosopulo, A. (1981): Zur gegenwärtigen Rückstandssituation bei cadmium, blei, quecksilber und arsen in fleisch und organen von schlachtrindern. Archiv für Lebensmittelhyygiene. 32: 181-200.

Kreuzer, W.; Kracke, W.; Sansoni, B. and Wissmath, P. (1978): Untersuchungen über den blei $(\mathrm{Pb})$ und cadmium $(\mathrm{Cd})$. Gehalt in Fleisch Und Organen von Schlachtrindern. 1. Rinder aus einem wenig umweltbelasteten Gebiet. Fleischwirtschaft. 58 (6) $1022-1030$. 
Monkiewicz, J.; Jaczewski, S.; Pawlina, E. and Radzanowska, G. (1986): Effect of emissions from copper foundry on the content of lead, copper and zinc in the feed, blood and organs of cows. Medycyna Weterynaryjna. 42 (7) 425-429.

Morcombe, P.; Petterson, D.; Ross, P. and Edwards, J. (1994): Soil and agronomic factors associated with cadmium accumulation in kidneys of grazing sheep. Australian Veterinary Journal. 71(12) 404-406.

Mousa, M. and Samaha, I. (1993): Cadmium, copper, lead, and zinc in carcasses of food animals. Alex. J. Vet. Science. 9 (3) 127-131.

National Academy of Sciences (1972): Lead, air borne lead in perspective. Committee on biologic effects of atmospheric pollutants. Division of Medical Sciences, National Research Council (NRC), Nath. Acad. Sci. (NAS), Washington, D. C.

Ragan, H. and Mast, T. (1990): Cadmium inhalation and male reproductive toxicity. Rev. Environ. Contam. Toxicol. 114:122.

Robards, K. and Worsfold, P. (1991): Cadmium: toxicology and analysis. Analyst. 116: 549-568

Ronneau, C. and Cara, J. (1984): Correlations of element deposition on pastures with analysis of cow's hair. Sci. Total Environ. 39: $135-142$.

Rotkiewiez, T.; Stypula, J.; Sikora, J.; Kleczkowski, M. and Siwek, Z. (1979): Chroninc cadmium poisoning in bulls. Medycyna Weterynaryjna. 35 (8): 486-488.

Royal Commission on Environmental Pollution (1979): The effect of pollution on agriculture. $7^{\text {th }}$ report, Agriculture and pollution, Cmnd. 7644. Chap. VI, pp. 161-188. HMSO, London.

Salisbury, C.; Chan, W. and Saschenbrecker, P. (1991): Multielement concentration in liver and kidney tissues from five species of Canadian slaughter animals. J. Assoc. Off. Anal. Chem. 74 (4) 587-591.

Schraishuhn, J.; Kaufer-Weisis, I. and Weisis, E. (1992): Light and electron microscopy of kidney from calves given subtoxic amounts of lead. Berliner und Munchener Tieraztliche Wochenschrift. 105(9): 290-293.

Sharma, R.; Street, J.; Shupe, J. and Bourcier, D. (1982): Accumulation and depletion of cadmium and lead in tissues and milk of lactating cows fed small amounts of these metals. Journal of Dairy Science. 65: 972-979. 
Staessen, J.; Buchet, J.; Ginucchio, G.; Lauwerys, R.; Lijnen, P.; Roels, $H$. and Fagard, R. (1996): Public health implications of environmental exposure to cadmium and lead: an overview of epidemiological studies in Belgium. J. Cardiovasc. Risk. 3 (1) 26-41.

Thiel, C. (1994): Optical and electron microscopy applied to renal glomeruli of calves given small amounts of lead. Ph. D. Thesis. Fachbereich Veterinarmedizin Justus Liebig Universität, Giessen, Germany.

Van Der Veen, N. and Vreman, K. (1986): Transfer of cadmium, lead, mercury and arsenic from feed into various organs and tissues of fattening lambs. Netherlands Journal of Agricultural Science. 34 (2) 143-153.

Van Hassel, J.; Ney, I. and Garling, J. (1980): Heavy metals in a stream ecosystem at sites near highways. Trans. Amer. Fish Soc. 109: 636.

Venäläinen, E.; Niemi, A. and Hirvi, T. (1996): Heavy metals in tissues of hares in Finland, 1980-82 and 1992-93. Bull. Environ. Contam. Toxicol. 56: 251-258.

Vos, G.; Hovens, j. and Deflt, W. (1987): Arsenic, cadmium, lead and mercury in meat, livers and kidneys of cattle slaughtered in the Netherlands during 1980-1985. Food addit. Contam. 4 (1) 73-88.

Wells, G.; Howell. J. and Gopinath, C. (1975): Experimental lead encephalopathy of calves. Histological observation on the nature and distribution of the lesions.

WHO (1977): Environmental Health criteria. No. 3, lead. World Health Organization, Geneva.

WHO (1980): Recommended Health Based limits in Occupational Exposure to Heavy Metals. Technical Report series No. 647. World Health Organization, Geneva.

WHO (1995): Environmental Health criteria series No. 165. Inorganic lead. World Health Organization, Geneva. 